ОСОБЕННОСТИ НАКОПЛЕНИЯ, ЛОКАЛИЗАЦИЯ И КАЧЕСТВЕННЫЕ ПОКАЗАТЕЛИ ЖИРОВОЙ ТКАНИ БЫЧКОВ

В ЗАВИСИМОСТИ ОТ ИХ ПОРОДНОЙ ПРИНАДЛЕЖНОСТИ

\title{
FEATURES OF ACCUMULATION, LOCALIZATION AND QUALITY INDICATORS OF THE BOVINE ADIPOSE TISSUE DEPENDING ON THEIR BREED MEMBERSHIP
}

${ }^{I}$ Ранделин A.B., доктор сельскохозяйственных наук, профессор

${ }^{I}$ Ранделина В.B., кандидат сельскохозяйственных наук

${ }^{2}$ Ранделин Д.А., доктор биологических наук

${ }^{1}$ Randelin A.V., doctor of agricultural sciences, professor

${ }^{I}$ Randelina $\boldsymbol{V} . \boldsymbol{V}$., candidate of agricultural sciences

${ }^{I}$ Randelin D.A., doctor of biological sciences

${ }^{1}$ Поволжский научно-исследовательский институт производства

и переработки мясомолочной продукции, Волгоград

${ }^{2}$ Волгоградский государственный аграрный университет

${ }^{1}$ Volga region research institute of manufacture and processing

of meat-and-milk production, Volgograd

${ }^{2}$ Volgograd state agrarian university

В работе изложен материал, характеризующий особенности накопления, локализации жировой ткани в теле выращиваемых бычков русской комолой, казахской и калмыцкой пород мясного скота.

Приведены сравнительные данные химического состава и физических свойств подкожной, межмышечной и внутренней жировой ткани.

The article presents the material characterizing the features of accumulation, localization of adipose tissue grown by bulls of Russian komolaya, Kazakhskaya and Kalmykskaya breeds of beef cattle.

The comparative data of chemical composition and physical properties of subcutaneous, intermuscular and internal adipose tissue are presented.

Ключевые слова: порода, мясная продуктивность, качество говядины, химический и биохимический состав мяса. 
Keywords: breed, meat productivity, quality of beef, chemical and biochemical composition of meat.

Введение. Производство говядины - перспективный путь для развития животноводства. Вкусовые, питательные, кулинарно-технологические свойства мяса зависят во многом от содержания в нем жировой ткани $[1,2,3,4,5]$. От молодняка мясных пород, откормленного по специальным технологиям, получают мраморное мясо, которое обладает высокими вкусовыми свойствами $[6,7$, $8,9]$. В связи с этим является актуальным изучение характера накопления жировой ткани в организме подопытных бычков, её локализации, химического состава и физических свойств.

Наиболее распространенными в регионе Нижнего Поволжья мясными породами крупного рогатого скота являются: казахская белоголовая, калмыцкая, русская комолая.

Материал и методы. Экспериментальная работа выполнялась в ООО «Тингутинское» Светлоярского района Волгоградской области. Объектом изучения были бычки русской комолой (I гр.), казахской белоголовой (II гр.) и калмыцкой пород (III гр.). Подопытные группы бычков формировали при достижении ими возраста 8 мес.

Подопытные бычки в стойловый период (с 8- до 11-месячного возраста) содержались по мясной технологии. Летом (с 11- до 17-месячного возраста) бычки выпасались на естественных пастбищах

Уровень кормления бычков был рассчитан на среднесуточный прирост живой массы 1000 г.

Результаты и обсуждение. Исследования показали, что в организме молодняка русской комолой породы (I группа) было синтезировано жировой ткани больше, чем у сверстников казахской белоголовой (II группа), на 1,53 кг, или 5,24\% (Р>0,95), и калмыцкой (III группа) - на 3,95 кг, или 14,74\% $(\mathrm{P}>0,999)$.

У животных I группы межмышечной жировой ткани было отложено больше, чем у сверстников II и III групп, соответственно на 0,16 кг, или $1,94 \%$, и 1,55 кг, или 7,0\% (Р>0,999).

По количеству подкожной жировой ткани, синтезированной в организме подопытных бычков изучаемых пород, существенных различий не установлено (таблица 1).

Таблица 1 - Локализация жировой ткани в теле подопытных бычков $(\mathrm{M} \pm \mathrm{m})$

\begin{tabular}{|l|c|c|c|c|c|c|}
\hline \multirow{3}{*}{ Показатель } & \multicolumn{5}{|c|}{ Группа } \\
\cline { 2 - 7 } & \multicolumn{2}{|c|}{ I } & \multicolumn{2}{c|}{ II } & \multicolumn{2}{c|}{ III } \\
\cline { 2 - 7 } & Macca, кг & $\%$ & Macca, кГ & $\%$ & Macca, кг & $\%$ \\
\hline Подкожная & $7,45 \pm 0,13$ & 24,23 & $7,65 \pm 0,09$ & 26,18 & $7,28 \pm 0,10$ & 27,16 \\
\hline
\end{tabular}




\begin{tabular}{|l|c|c|c|c|c|c|}
\hline Межмышечная & $8,40 \pm 0,08$ & 27,32 & $8,24 \pm 0,05$ & 28,20 & $7,85 \pm 0,07$ & 29,29 \\
\hline Внутреннее сало & $14,90 \pm 0,16$ & 48,45 & $13,33 \pm 0,09$ & 45,62 & $11,67 \pm 0,08$ & 43,55 \\
\hline Всего & $30,75 \pm 0,36$ & 100,0 & $29,22 \pm 0,41$ & 100,0 & $26,80 \pm 0,32$ & 100,0 \\
\hline
\end{tabular}

Вместе с тем исследования показали, что в теле бычков русской комолой породы (I группа) была наиболее низкой удельная масса подкожной $(24,13 \%)$ и высокой - межмышечной жировой ткани $(27,32 \%)$ и внутреннего сала $(48,45 \%)$.

В зависимости от породной принадлежности нами были установлены различия по химическому составу жировой ткани подопытных животных (таблица 2).

Таблица 2 - Химический состав внутреннего жира сырца, \% (M $\pm \mathrm{m})$

\begin{tabular}{|l|c|c|c|}
\hline \multirow{2}{*}{\multicolumn{1}{|c|}{ Показатель }} & \multicolumn{3}{|c|}{ Группа } \\
\cline { 2 - 4 } & I & II & III \\
\hline Влага & $12,47 \pm 0,21$ & $13,34 \pm 0,16$ & $13,38 \pm 0,19$ \\
\hline Сухое вещество & $87,53 \pm 0,21$ & $86,66 \pm 0,16$ & $86,62 \pm 0,19$ \\
\hline Протеин & $2,79 \pm 0,05$ & $3,17 \pm 0,03$ & $3,24 \pm 0,06$ \\
\hline Жир & $84,56 \pm 0,27$ & $83,32 \pm 0,22$ & $83,21 \pm 0,31$ \\
\hline Зола & $0,18 \pm 0,01$ & $0,17 \pm 0,01$ & $0,17 \pm 0,01$ \\
\hline
\end{tabular}

Опытным путем установлено, что во внутреннем жире-сырце животных I группы (русская комолая) больше содержалось сухого вещества, чем у сверстников II (казахская белоголовая) и III (калмыцкая) групп, на 0,87 $(\mathrm{P}>0,95)$ и $0,91 \%(\mathrm{P}>0,95)$, жира - на $1,24(\mathrm{P}>0,95)$ и $1,35 \%(\mathrm{P}>0,95)$. Это указывает на зависимость качественных показателей мясного сырья и готовой продукции от химического состава и технологических свойств жировой ткани.

При этом в жировой ткани молодняка II и III групп содержание протеина было выше, чем у сверстников I группы, соответственно на 0,38 $(\mathrm{P}>0,99)$ и $0,45(\mathrm{P}>0,999)$. Таким образом, химический состав жировой ткани был лучшим у молодняка I группы.

Опытные данные, полученные в результате проведенных исследований, показали, что физические свойства жировой ткани подопытных бычков имели довольно существенные различия. Так, температура плавления подкожной жировой ткани бычков I группы в сравнении со сверстниками II и III групп была ниже соответственно на 0,22 и $0,27^{\circ} \mathrm{C}$, межмышечной - на 0,17 и $0,22{ }^{\circ} \mathrm{C}$ и внутреннего сала - на 0,13 и $0,24^{\circ} \mathrm{C}$ (таблица 3 ).

Таблица 3 - Физические свойства жировой ткани подопытных бычков, \% $(\mathrm{M} \pm \mathrm{m})$

\begin{tabular}{|l|r|r} 
I & II & III
\end{tabular}




\begin{tabular}{|l|r|r|r|}
\hline \multicolumn{4}{|c|}{ Подкожная } \\
\hline Температура плавления, ${ }^{\circ} \mathrm{C}$ & $42,09 \pm 0,11$ & $42,31 \pm 0,21$ & $42,36 \pm 0,17$ \\
\hline Йодное число & $37,56 \pm 0,19$ & $37,65 \pm 0,16$ & $37,74 \pm 0,13$ \\
\hline \multicolumn{4}{|c|}{ Межмышечная } \\
\hline Температура плавления, ${ }^{\circ} \mathrm{C}$ & $43,10 \pm 0,14$ & $43,27 \pm 0,12$ & $43,32 \pm 0,15$ \\
\hline Йодное число & $36,21 \pm 0,09$ & $36,74 \pm 0,14$ & $36,68 \pm 0,10$ \\
\hline \multicolumn{4}{|c|}{ Внутреннее сало } \\
\hline Температура плавления, ${ }^{\circ} \mathrm{C}$ & $43,27 \pm 0,17$ & $43,40 \pm 0,12$ & $43,51 \pm 0,19$ \\
\hline Йодное число & $30,42 \pm 0,11$ & $30,65 \pm 0,16$ & $30,78 \pm 0,10$ \\
\hline
\end{tabular}

По йодному числу жировой ткани показатель был выше у бычков II и III групп, подкожной - на 0,09 и 0,18\% (P>0,95), межмышечной - на 0,53 и $0,47 \%(\mathrm{P}>0,99)$, внутреннего сала - на 0,13 и 0,36\% (P>0,95) по сравнению с аналогами I группы.

Таким образом, характер формирования качественных показателей жировой ткани в организме молодняка крупного рогатого скота зависит от его породной принадлежности.

\section{Библиографический список}

1. Ранделин, Д.А. Особенности роста и развития бычков разных специализированных пород / Д.А. Ранделин, И.В. Сазонова, Е.В. Левковская // Известия Нижневолжского агроуниверситетского комплекса: наука и высшее профессиональное образование. - 2012. - № 4 (28). - С. 135-139.

2. Горлов, И.Ф. Эффективность выращивания на мясо бычков специализированных мясных пород / И.Ф. Горлов, Д.А. Ранделин, А.К. Натыров // Вестник Калмыцкого университета. - 2013. - 3 (19). - С. 14-20.

3. Горлов, И.Ф. Новые подходы к производству говядины на основе современных биоинженерных технологий: монография / И.Ф. Горлов, В.И. Левахин, Д.А. Ранделин, А.К. Натыров, Б.К. Болаев, О.А. Суторма. - Элиста: Калмыцкий государственный университет, 2015. - 248 с.

4. Горлов, И.Ф. Научно обоснованные технологии производства конкурентно способной говядины: монография / И.Ф. Горлов, А.И. Беляев, А.Н. Струк, Г.В. Волоколупов, М.Е. Спивак, Д.А. Ранделин. - Москва-Волгоград: Вестник РАСХH, 2009. - 274 с.

5. Горлов, И.Ф. Качественные показатели мяса подопытных бычков казахской белоголовой породы разных генотипов / И.Ф. Горлов, А.Н. Сивко, О.А. Суторма, Д.А. Ранделин // Известия Нижневолжского агроуниверситетского комплекса: наука и высшее профессиональное образование. - 2015. № 4 (40). - C. 87-92. 
6. Ранделин, Д.А. Влияние скрещивания на мясную продуктивность бычков и качественные показатели их мяса / Д.А. Ранделин // Все о мясе. 2010. - № 1. - С. 34-36.

7. Левахин, В.И. Повышение продуктивного потенциала скота казахской белоголовой породы на основе оптимизации генетических и паратипических факторов: монография / В.И. Левахин, Х.А. Амерханов, В.В. Калашников, И.Ф. Горлов, В.Л. Королев, О.А. Суторма. - Москва, 2013. - 340 с.

8. Горлов, И.Ф. Интенсификация производства высококачественной говядины в условиях Нижнего Поволжья: монография / И.Ф. Горлов, Б.К. Болаев, А.А. Кайдулина, А.К. Натыров, А.В. Ранделин, М.И. Сложенкина, А.К. Натыров. - Элиста: Калмыцкий государственный университет, 2016. $216 \mathrm{c}$.

9. Горлов, И.Ф. Интенсификация производства продуктов мясного скотоводства на основе прогрессивных технологий селекции и кормления животных: монография / И.Ф. Горлов, С.Н. Шлыков, А.К. Натыров, М.И. Сложенкина, Б.К. Болаев [и др.]. - Элиста: Калмыцкий государственный университет, 2017. - $230 \mathrm{c}$. 